tion to Nature in November of the same year. (NATURE, vol. lvii. p. 173).

"The second memoir on the subject appeared in the Transactions of the Royal Dublin Society for June I899 (vol. iii. Ser. ii. pp. 7 et seq.), having been read by Prof. Preston in June of that year.

"He here offers an explanation of the quartet form analogous to Prof. FitzGerald's suggestion that the ionic orbits will vibrate with definite period about their position of rest in the magnetic field, and records the observation that, for corresponding lines of the natural groups or series of Kayser and Runge, the theoretic condition obtains.

"He further, in this communication, suggests a law which apparently involves the far-reaching conclusion that structural features in common are possessed by chemically related atoms. Although such a conclusion commends itself for other well-known reasons, so direct a proof as is involved in 'Preston's Law' had hardly been hitherto adduced. This law he illustrates by the case of three substances:-magnesium, cadmium and zinc. The law expresses the fact that not only are similar lines in the series of chemically related elements similarly modified by the magnetic field, but that the value

$$
\frac{d \lambda}{\lambda^{2}}
$$

is, in these cases, the same. The importance of this law, whether the theory of ions is accepted or not, is accentuated in M. Cotton's able review of the present state of the investigation. (Le Phénomène de Zeeman, Scientia, October I 899.)

"In the course of these researches Prof. Preston was gradu. ally increasing the strength of his magnetic field, and lately was using a magnet built to his own design attaining a field of 40,000 C. G.S. units. The design of this magnet is original, but a published account of it has not yet appeared.

"With the aid of this powerful instrument he was able to announce, in the addendum to his paper in the Trans. R.D.S last referred to, that the quartet form hitherto noticed is really a sextet, the outer lines being feebly bipartate, that the normal triplets are not further resolved, and that the diffuse triplets are, in fact, nonets, consisting of unequally luminous lines.

"Contemporaneously with these papers, others, mainly recapitulatory, appeared in the Philosophical Magazine and in NATURE.

"A clear and lucid account of the whole matter is also to be found in the report of Prof. Preston's lecture before the Royal Institution, appearing in NATURE (vol. Ix. June 22, I899).

"It is satisfactory to find how clearly in his later papers Prof. Preston recognises the pioneer work of Dr. G. J. Stoney (upon whom this Society conferred the Boyle Medal last year).

"We have in the foregoing referred to Prof. Preston's leading work and to that specially qualifying him to receive the Boyle Medal, but before this work appeared, he was already known as a writer on science of high standing. I His text-books on Light and Heat are at once characterised by a clear and pleasant style and a thorough grasp of the subjects treated. These works may each fairly claim to be advances on any previous English textbooks of the same scope.

"Prof. Preston is also the author, in part, of a well-known text-book on 'Spherical Trigonometry,' as well as of several scientific papers, which are all marked by his ingenuity and thoroughness."

All who have known Thomas Preston will share in a feeling more deeply founded in human nature than the regret for his "unfulfilled rentwn"-regretful as this assuredly is. The loss of his friendship will be felt even more keenly than the strong sense of the great loss science has experienced by his early death.

\section{GEORGE JAMES SYMONS, F.R.S.}

$\mathrm{SCIENCE}$ in general, and Meteorology in particular, has lost an ardent worker by the death of Mr. G. J. Symons, F.R.S., the indefatigable founder of the British Rainfall Organisation. He had been enjoying good health until the evening of February 14, when he was stricken with paralysis, from which he never rallied, but passed peacefully away on the afternoon of Saturday last, March 10.

George James Symons was born at Pimlico on August

6,1838 . While quite a lad he became interested in natural phenomena, and very early commenced regular weather observations. His love of this became so strong that his parents were ultimately obliged to permit him to follow this branch of science, although he was warned by such a high authority as Mr. James Glaisher, F.R.S., that "science would not pay." He served under Admiral FitzRoy in the Meteorological Department of the Board of Trade for a few years, and then began his life-work of collecting rainfall statistics. His first annual volume of "British Rainfall" was for the year 1860 , and this contained records from 168 stations. How this work grew under his guidance and ceaseless energy is seen from the fact that in the volume for $187 \mathrm{I}$ he published records from I 504 stations; for $188 \mathrm{r}$, from 2145 stations ; for I $89 \mathrm{I}$, from 2799 stations; while for 1898 he was able to publish records from 3404 stations. The information and data thus collected soon became of great assistance to civil engineers and cthers engaged in questions of water supply. In the course of time Mr. Symons became the greatest authority on the distribution of rainfall over the country, and was an indispensable witness at Parliamentary Committees on questions of water supply. The Albert Medal of the Society of Arts was, in 1897, awarded to Mr. Symons "for the services he had rendered to the United Kingdom by affording to engineers engaged in the water supply and the sewage of towns a trustworthy basis for their work, by establishing and carrying on during nearly forty years systematic observations (now at over 3000 stations) of the rainfall of the British Isles, and by recording, tabulating, and graphically indicating the results of these observations in the annual volumes published by himself." It is a satisfaction to know that the rainfall organisation will not cease with his death, but will be carried on by his co-adjutor, Mr. H. Sowerby Wallis.

In 1866 he commenced the publication of Symons's Monthly Meteorological Magazine, which has been continued up to the present time.

Mr. Symons was elected a Fellow of the Royal Meteorological Society in 1856 , and served on the Council from 1863 . He was President in $1880-81$, and Secretary in $1873^{-79}$, and also in $1882-99$. He was elected President a second time in January last, in view of the Jubilee of the Society taking place during the present year; but, owing to his being seized with paralysis, he had to resign this office at the following Council meeting. He was elected a Fellow of the Royal Society in 1878, and at the last anniversary meeting was made a member of the Council.

Mr. Symons was a regular attendant at the meetings of the British Association, and served on several of the committees. He was also for some time on the Council of the Royal Botanic Society and of the Sanitary Institute. He was also Chevalier de la Légion d'Honneur.

Mr. Symons was a keen bibliophile, and had a very valuable meteorological library. Among his publications may be mentioned: Merle's MSS. "Consideraciones Temperiei pro 7: annis I 337-1 344 "; "Rain-how, when, where, why it is measured" " ( 3 editions); "The Floating Island of Derwentwater"; and "The East Anglia Earthquake." He was a most genial and amiable man, and had the power of drawing around him a vast number of friends and voluntary observers, who will deeply mourn his loss.

\section{NOTES.}

Prof. E. Fischer, of the University of Berlin, has been elected a correspondant of the Paris Academy of Sciences, in the Section of Chemistry.

We regret to see the announcement of the death of Dr. William Marcet, F.R.S., at Luxor, Egypt, in his seventy-second year. The death is also announced of Mr. William Thorpe, a vice-president of the Society of Chemical Industry. 